\title{
FAKTOR-FAKTOR PENYEBAB RENDAHNYA FUNGSI SHIP CRANE TERHADAP PROSES BONGKAR MUAT MV. MADISON
}

\author{
Dwi Antoro ${ }^{a}$, Purwantono ${ }^{b}$ dan Dawata Afnan ${ }^{c}$ \\ ${ }^{a}$ Dosen Program Studi Nautika PIP Semarang \\ ${ }^{\mathrm{b}}$ Dosen Program Studi Teknika PIP Semarang \\ ${ }^{\mathrm{c}}$ Taruna (NIT.50134838.N) Program Studi Nautika PIP Semarang
}

\begin{abstract}
ABSTRAK
Dalam proses bongkar muat di sebuah kapal container sebuah alat bongkar muat sangatlah dibutuhkan dan juga kondis yang baik juga diperlukan dalam proses bongkar muatnya. Berdasarkan fakta yang diperoleh penulis tertarik untuk membuat penelitian dengan judul "Optimalisasi Penggunaan Ship Crane Guna Memperlancar Proses Bongkar Muat MV. Madison Di Pelabuhan Nabire”. Dalam melaksanakan perawatan peralatan bongkar muat ada beberapa permasalahan yang dihadapi yaitu : bagaimana pengaruh rutinitas perawatan alat bongkar muat yang kurang baik terhadap kelancaran proses bongkar muat dan upaya-upaya apa yang dilakukan untuk mengoptimalkan penggunaan peralatan bongkar muat di pelabuhan. Sesuai dengan permasalahan yang dihadapi dalam melaksanakan perawatan alat bongkar muat muncul jawaban sementara atas masalah yang dikemukakan, diantaranya diduga bahwa gangguan yang dialami oleh alat bongkar muat di kapal MV. Madison disebabkan oleh kurangnya perawatan alat bongkar muat serta diduga bahwa gangguan yang dialami alat bongkar muat di kapal MV. Madison dapat menghambat proses bongkar muat. Berdasarkan analisa bahwa perawatan alat bongkar muat tidak dapat dilaksanakan secara teratur sehingga mengakibatkan sering terjadinya kerusakan pada alat bongkar muat yang tentu saja proses pemuatannya ataupun pembongkaran menjadi terlambat atau terganggu. Hal yang mebuat proses bongkar muat terganggu dikarenakan peralatan yang menunjang pelaksanaan perawatan alat bongkar muat kurang memadai sehingga kerja crew kapal kurang maksimal dan masalah waktu yang tidak dimiliki karena seringnya kapal melakukan operasi bongkar muat membuat crew selalu sibuk dengan operasi kapal yang lebih penting.
\end{abstract}

Kata kunci : penggunaan ship crane, proses bongkar muat

\section{PENDAHULUAN}

Di bidang transportasi laut khususnya pengangkutan barang atau muatan, telah terjadi perubahan dan peningkatan yaitu dengan hadirnya peti kemas (container) yang menjadi suatu sistem baru. Sekarang ini sudah berdampak menyeluruh pada sistem pengangkutan muatan yang makin lama makin meningkat. Kemajuan sistem peti kemas yang cukup pesat ini tidak lain bertujuan mengantar muatan secara aman, cepat dan efisien dari pelabuhan asal hingga sampai pada pelabuhan tujuan untuk menghindari kerusakan muatan sekecil mungkin.

Pengangkutan barang atau muatan dengan menggunakan peti kemas di Amerika Serikat dimulai sekitar tahun 1950 oleh Firma Mc Lean Trucking Company, milik seorang pengusaha bernama Malcolm Mc Lean. Untuk perluasan pelayaran melalui laut maka pada tahun 1957, Mc Lean membeli Perusahaan Pelayaran Pan Atlantic Steamship Company, kemudian merubah susunan ruang muatan kapalnya menjadi sistem peti kemas dan selanjutnya 
perusahaan tersebut merupakan cikal bakal dari Sea Lan Service Inc.

Penerapan sistem pengangkutan dengan peti kemas di Indonesia dimulai saat di mana peti kemas dimulai sejak tahun 1970-an di mana penanganannya masih secara konvensional dan sejak saat itulah dimulai pembangunan pelabuhan peti kemas di Tanjung Priok sebagai pelabuhan utama di Indonesia saat itu dilengkapi dengan gantry crane dan truktruk khusus pengangkut peti kemas (Tumbel, 1991:3). Dalam hal ini pula terkadang menyulitkan pihak kapal, yang terkadang di pelabuhan tertentu tidak menyediakan alat bongkar muat berupa crane atau gantry crane. Seperti yang dialami oleh penulis bahwa di daerah yang terpencil seperti Nabire sangat ketergantungan dengan pasokan yang di kirim melalui kapal penulis. Jika tidak ada sarana tersebut hal yang paling diutamakan adalah ship's crane, yang terkadang ini pun sering terjadi kendala. Mengakibatkan terhambatnya proses bongkar muat.

Pengaturan dan pengamanan peti kemas yang baik dan benar serta memenuhi aturan pemuatan secara langsung menjamin keselamatan muatan itu sendiri, akan tetapi pada kenyataannya semua hal yang berkaitan dengan pemuatan, pengaturan, dan sistem pengamanan peti kemas di atas kapal terkadang tidak sesuai aturan dan kemampuan kapal, sebagai contoh banyak perusahaan pelayaran di Indonesia yang mempunyai manajemen kurang baik khususnya pada kapal peti kemas memaksakan kapalnya untuk memuat peti kemas lebih dari kemampuan dan konstruksi dari kapal tersebut, padahal semua peralatan pendukung baik itu lashing dan kemampuan geladak untuk menahan beban diatasnya terkadang melebihi normal. Hal ini tentu saja sangat membahayakan dan mengancam kelangsungan pelayaran pada saat di perjalanan dan pada saat proses bongkar muat.
Adapun permasalahan yang dihadapi adalah kurangnya perawatan atas alat-alat bongkar muat di atas kapal dan kurangnya koordinasi antara pihak darat dan pihak kapal pada saat proses bongkar muat berlangsung. Hal itu juga disebabkan karena kondisi dari alat-alat bongkar muat yang sudah tidak memenuhi persyaratan dikarenakan usia yang sudah tua, serta tidak adanya penggantian atas alat-alat tersebut. Paradigma perusahaan yang menggunakan tambal sulam, menggunakan alat yang bekas atau suku cadang yang telah didaur ulang dari kapal lain yang di mana ini dapat merugikan alat bongkar muat itu sendiri.

Dengan demikian pelaksanaan proses bongkar muat dapat berjalan dengan lancer, demikian pula saat proses bongkar muat buruh yang bertugas atau operator dari gantry dan crane kurang memperhatikan atau kurang hati-hati saat bongkar muat peti kemas dari kapal atau pada saat memasukkan peti kemas ke kapal sehingga mengakibatkan peti kemas tersebut rusak. Masalah-masalah di atas terjadi di atas kapal MV. Madison. Oleh karena itu pengawasan saat bongkar dan muat maupun pengecekan peti kemas dan peralatannya harus selalu dilakukan secara teratur selama perjalanan sampai kapal tiba di pelabuhan yang dituju.

Berdasarkan uraian tersebut di atas penulis tertarik untuk mengadakan penelitian dengan judul "Optimalisasi penggunaan ship crane guna memperlancar proses bongkar muat MV. Madison di pelabuhan Nabire".

\section{KAJIAN PUSTAKA}

A. Tinjauan Pustaka

1. Optimal

Denifisi-denifisi optimal dari berbagai sumber:

a. Optimalisasi adalah suatu proses untuk mencapai hasil yang ideal atau optimalisasi (nilai efektif yang dapat dicapai). Optimalisasi dapat diartikan 
sebagai suatu bentuk mengoptimalkan sesuatu hal yang sudah ada, ataupun merancang dan membuat sesuatu secara optimal:

1) Optimum adalah kondisi yang terbaik atau yang paling menguntungkan;

2) Mengoptimalkan adalah usaha menjadikan paling baik, atau menjadi paling tinggi.

b. Optimalisasi adalah proses mengoptimalkan

(Wahyuningsih, 2010: 291). Menurut KBBI (Kamus Besar Bahasa Indonesia), kata optimalisasi diambil dari kata optimal yang berarti terbaik, tertinggi. Sedangkan pengoptimalan berarti proses, cara, perbuatan pengoptimalan (menjadikan paling baik atau paling tinggi). Jadi optimalisasi adalah sistem atau upaya menjadikan paling baik atau paling tinggi.

c. Menurut Pius Abdillah dan Danu Prasetya dalam bukunya Kamus Lengkap Bahasa Indonesia (2009:243), menyebutkan bahwa :

1) Mengoptimalkan adalah menjadikan sempurna, menjadikan paling tinggi, menjadikan maksimal;

2) Optimum adalah dalam kondisi yang baik, dalam kondisi yang paling menguntungkan.

\section{Penggunaan}

Penggunaan sendiri sebuah kata "penggunaan" merupakan kata benda (nominan) karena bisa di lihat dari cirinya nominan merupakan kata yang menyatakan nama dari seseorang, tempat, atau semua benda dan segala yang dibendakan. Dalam artian dalam kata ini dapat mewakili bagaimana sebuah benda atau alat dapat digunakan dan berfungsi dengan baik.

Dalam beberapa hal yang penulis temui di kapal, terkadang seorang crew yang bertugas mengoperasikan sebuah crane, tidak memiliki keahliah dan tidak memiliki dasar dalam mengoperasikan crane.

\section{Proses Bongkar Muat}

Menurut Arso Martopodan Soegiyanto dalam bukunya Penanganan dan Pengaturan Muatan (2004:30), menyebutkan bahwa proses bongkar muat adalah kegiatan mengangkat, mengangkut serta memindahkan muatan dari kapal ke dermaga pelabuhan atau sebaliknya. Sedangkan proses bongkar muat barang umum di pelabuhan meliputi stevedoring (pekerjaan bongkar muat kapal), cargo doring (operasi transfer tambatan), dan receiving / delivery (penerima / penyerahan) yang masing-masing dijelaskan di bawah ini :

a. Stevedoring (pekerjaan bongkar muat kapal)

$\begin{array}{lcr}\text { Menurut } & \text { Arso } & \text { Martopodan } \\ \text { Soegiyanto } & \text { dalam } & \text { bukunya } \\ \text { Penangganan } & \text { dan } & \text { Pengaturan }\end{array}$ Muatan (2004:30), menyebutkan bahwa stevedoring (pekerjaan bongkar muat kapal) adalah jasa pelayanan membongkar dari/kapal, dermaga, tongkang, truk atau muat dari/ke dermaga, tongkang, truk ke/dalam palka dengan menggunakan derek kapal atau yang lain.

Petugas stevedoring (pekerjaan bongkar muat kapal) dalam mengerjakan bongkar muat kapal, selain foreman (pembantu stevedor) juga ada beberapa petugas lain yang membantu stevedore (pemborong bongkar muat kapal), yaitu cargo surveyor perusahaan Proses Bongkar Muat (PBM), petugas barang berbahaya, administrasi, cargodoring (operasi transfer tambatan). 
Menurut Arso Martopo dan Soegiyanto dalam bukunya Penangganan dan Pengaturan Muatan (1990:30) cargodoring (operasi transfer tambatan) adalah pekerjaan mengeluarkan barang atau muatan dari sling pada lambung kapal di atas dermaga, mengangkut dan menyusun muatan di dalam gudang atau lapangan penumpukan dan sebaliknya. Dalam pelaksanaan produktifitas cargo doring dipengaruhi oleh tiga variabel yakni jarak yang ditempuh, kecepatan kendaraan, dan waktu tidak aktif (immobilisasi). Agar aktifitas cargo doring (operasi transfer tambatan) bisa berjalan produktif dan efisien, peralatan harus dimanfaatkan dengan baik. Agar down time (waktu terbuang) rendah maka perlu pemeliharaan peralatan dilaksanakan dengan baik dan secara teratur.

b. Receiving atau Delivery (penerima/ penyerahan)

Receiving atau Delivery adalah pekerjaan mengambil barang atau muatan dari tempat penumpukan atau gudang hingga menyusunnya di atas kendaraan pengangkut keluar pelabuhan atau sebaliknya.

Kegiatan receiving (penerima) ini pada dasarnya ada dua macam, yaitu :

1) Pola muatan angkutan langsung adalah pembongkaran atau pemuatan dari kendaraan darat langsung dari dan ke kapal.

2) Pola muatan angkutan tidak langsung adalah penyerahan atau penerimaan barang/peti kemas setelah melewati gudang atau lapangan penumpukan.

Terlambatnya operasi delivery (penyerahan) dapat terjadi disebabkan :

a) Cuaca buruk / hujan waktu bongkar / muatan dan kapal;

b) Terlambatnya angkutan darat, atau terlambatnya dokumen. c) Terlambatnya informasi atau alur dari barang.

c. Definisi Operasional

1) Deck Crane adalah crane deck atau suatu jenis alat bongkar muat kapal.

2) DWT adalah Dead Weight Tonnage atau jumlah bobot yang dapat diangkut kapal sejak kapal kosong hingga sarat maksimum yang diijinkan.

3) Ballast adalah Air laut yang dimasukan ke dalam tangki khusus yang digunakan untuk menegakkan dan meningkatkan stabilitas kapal.

4) Check List adalah Merupakan daftar pertanyaan yang harus diisi oleh kapal atau terminal untuk menjamin keselamatan kapal, terminal dan orang-orang yang terlibat serta lingkungan laut.

5) Mast (tiang), batang baja yang berfungsi untuk menahan batang pemuat dan blok-blok serta wire pada mesin derek.

6) Boom (batang pemuat), sebuah pipa panjang baja yang pangkalnya dihubungkan ke tiang kapal, yang mempunyai daya angkut 3-5ton atau lebih. Panjangnya sedemikian rupa sehingga kalau diturunkan sampai sudut 25 derajat dengan bidang datar maka tali muat dan kait muat harus bisa mencapai $2,5 \mathrm{~m}$ di lambung kapal.

7) Derrick Winch (mesin derek), mesin pada derek yang berguna untuk menggerakkan batang pemuat, yang konstruksinya dari besi yang terdiri dari pelindung kawat reep, mesinnya dan terutama tromol bebas atau kepala derek dibuat dengan sistem las.

8) Winch roller (gulungan mesin derek) adalah mesin pada derek yang digunakan sebagai tempat untuk menggulung wire. 
9) Crew adalah suatu kesatuan orang yang bekerja di atas kapal.

B. Kerangka Pikir Penelitian

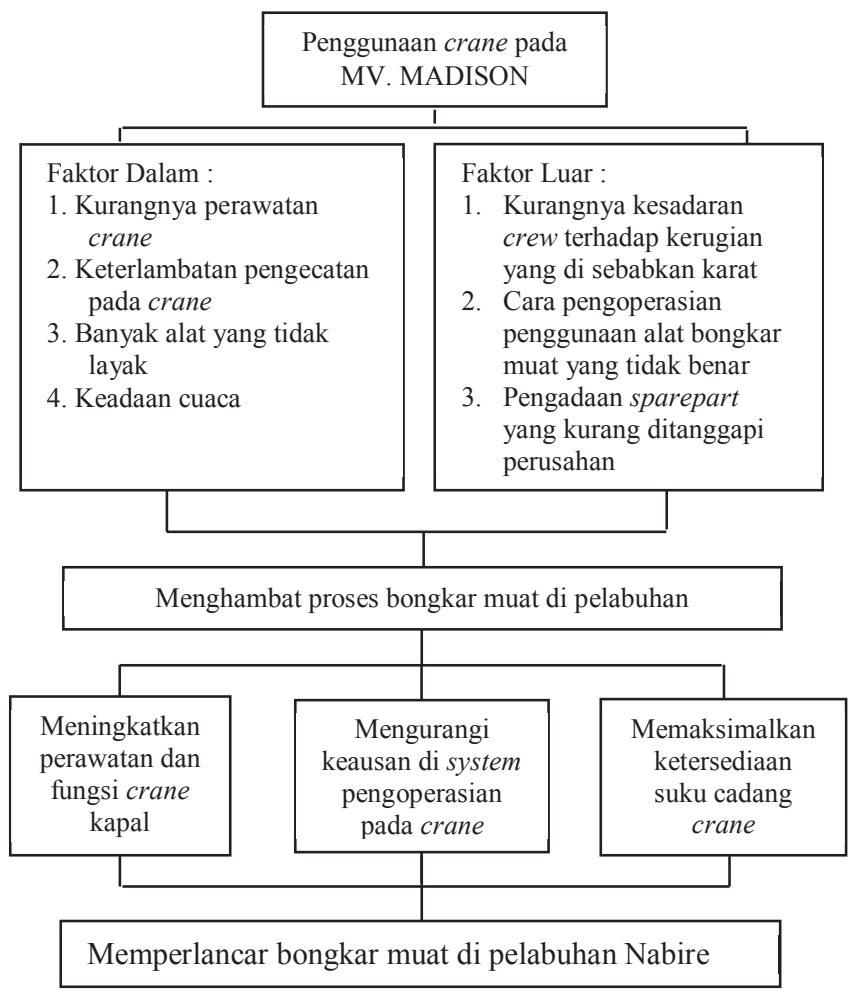

Gambar Kerangka Pikir

\section{METODOLOGI}

\section{A. Metode Penelitian}

Metode penelitian yang digunakan oleh penulis dalam penyampaian masalah adalah metode deskriptif kualitatif, untuk menggambarkan dan menguraikan yang diteliti. Menurut Sukardi dalam bukunya Metodologi Penelitian Pendidikan (2008:157), metode deskriptif merupakan metode penelitian yang berusaha menggambarkan dan menginterpretasi objek sesuai apa adanya, dengan tujuan menggambarkan secara sistematis fakta karakteristik objek yang diteliti secara tepat.

Menurut Moleong dalam bukunya Metodologi Penelitian Kualitatif (2006:6), penelitian kualitatif adalah penelitian yang bermaksud untuk memahami fenomena tentang apa yang dialami oleh subjek penelitian misalnya perilaku, persepsi, motivasi, tindakan-tindakan dan lain-lain, secara holistik dan dengan cara depenelitian dalam bentuk kata-kata dan bahasa, pada suatu konteks khusus yang alamiah dengan memanfaatkan berbagai metode ilmiah.

Di dalam pembahasan nanti penulis berusaha memaparkan hasil dari semua studi dan penelitian mengenai suatu yang diperoleh, baik hal-hal yang bersifat teori juga memuat hal-hal yang bersifat praktis dalam artian bahwa selain ditulis dari beberapa literatur buku, juga bersumber dari penelitian yang terdapat dalam buku kemaritiman. Penggunaan aspek observasi atau pengamatan sangat berperan dalam penulisan penelitian ini.

Selain penulisan menggunakan metode deskriptif kualitatif, penulis juga menggunakan teknik USG (Urgentcy Seriousness and Growth) Kepner dan Tragoe (1981) menyatakan pentingnya suatu masalah dibandingkan masalah lainnya dapat dilihat dari 3 aspek berikut :

1. Bagaimana gawatnya masalah dilihat dari pengaruhnya sekarang ini terhadap produktivitas, orang, dan sumber dana dan daya?

2. Bagaimana mendesaknya dilihat dari waktu yang tersedia?

3. Bagaimana perkiraan yang terbaik mengenai kemungkinan berkembangnya masalah?

Pada penggunaan matriks USG (Urgentcy Seriousness and Growth) untuk menentukan suatu masalah yang prioritas, terdapat tiga faktor yang perlu dipertimbangkan. Ketiga faktor tersebut adalah Urgency, Seriousness, dan Growth.

1. Urgency berkaitan dengan mendesaknya waktu yang diperlukan untuk menyelesaikan masalah tersebut. Semakin mendesak suatu masalah untuk diselesaikan maka semakin tinggi urgensi masalah tersebut.

2. Seriousness berkaitan dengan dampak dari adanya masalah tersebut terhadap organisasi. Dampak ini terutama yang menimbulkan kerugian bagi organisasi seperti dampaknya terhadap 
produktivitas, keselamatan jiwa manusia, sumber daya atau sumber dana. Semakin tinggi dampak masalah tersebut terhadap organisasi maka semakin serius masalah tersebut.

3. Growth berkaitan dengan pertumbuhan masalah. Semakin cepat berkembang masalah tersebut maka semakin tinggi tingkat pertumbuhannya. Suatu masalah yang cepat berkembang tentunya makin prioritas untuk diatasi permasalahan tersebut.

Untuk mengurangi tingkat subyektivitas dalam menentukan masalah prioritas, maka perlu menetapkan kriteria untuk masing-masing unsur USG tersebut. Umumnya digunakan skor dengan skala tertentu. Misalnya penggunaan skor skala 1-5. Semakin tinggi tingkat urgensi, serius, atau pertumbuhan masalah tersebut, maka semakin tinggi skor untuk masing-masing unsur tersebut.

Penggunaan metode USG dalam menentukan prioritas masalah dilaksanakan apabila pihak perencanaan telah siap mengatasi masalah yang ada, serta hal yang sangat dipentingkan adalah aspek yang ada di organisasi dan aspek dari masalah itu sendiri. Oleh karena itu di dalam pembahasan nanti penulis berusaha memaparkan hasil dari semua studi dan penelitian mengenai suatu yang diperoleh, baik hal-hal yang bersifat teori juga memuat hal-hal yang bersifat praktis, dalam artian bahwa selain ditulis dari beberapa literatur buku, juga bersumber dari penelitian yang juga terdapat dalam buku kemaritiman. Penggunaan aspek observasi atau pengamatan sangat berperan dalam penulisan penelitian ini.

Adapun hal-hal yang diamati adalah tentang perawatan alat bongkar muat terutama batang pemuat crane, yang kegiatannya dilaksanakan di kapal MV. Madison dengan adanya penelitian ini diharapkan hubungan antara pokok permasalahan dengan metode pemecahannya akan lebih jelas, sehingga selanjutnya dapat dicari usaha dan upaya untuk menanggulangi masalah tersebut.

B. Lokasi Penelitian

Menurut Sukardi dalam bukunya Metodologi Penelitian Pendidikan (2003:53), menerangkan bahwa yang dimaksud dengan tempat penelitian yaitu tempat dimana proses studi yang digunakan untuk memperoloh pemecahan masalah penelitian berlangsung. Penelitian ini dilakukan selama penulis melaksanakan praktek laut di atas kapal MV. Madison PT. SPIL (Salam Pasifik Indonesia Line). Pada saat penulis melaksanakan praktek laut selama satu tahun sekaligus menjadi anggota dalam proses rutinitas merawat alat bongkar muat selama dari pelabuhan muat ke pelabuhan bongkar.

\section{Populasi}

Menurut Handari Nawawi dalam bukunya Metode Penelitian Bidang Sosial (1983:141), menyebutkan bahwa populasi adalah keseluruhan objek penelitian yang dapat terdiri dari manusia, benda-benda, hewan, tumbuh-tumbuhan, gejala-gejala, nilai tes atau periatiwa-peristiwa sebagai sumber data yang memiliki karakteristik tertentu di dalam suatu penelitian. Dalam hal ini yang merupakan populasi dari penelitian yang dilakukan oleh penulis ialah alat bongkar muat jenis crane yang ada di atas kapal MV. Madison dan besarnya populasi adalah 3 (tiga) sesuai dengan jumlah alat bongkar muat yang ada di atas kapal MV. Madison.

\section{Teknik Sampling}

Menurut S. Nasution dalam bukunya Metode Research (2006:86), menyebutkan bahwa sampling adalah memilih sejumlah tertentu dari keseluruhan populasi, sedangkan teknik sampling adalah teknik yang digunakan untuk menetapkan siapa yang akan dijadikan sampel, besar sampel dan bagaimana sampel ditentukan. Dalam penelitian ini penulis menggunakan teknik pengambilan sampel dengan cara sumber data dari pertimbangan tertentu. 
Pertimbangan tertentu ini misalnya orang tersebut yang dianggap paling tahu tentang apa yang kita harapkan, atau dia sebagai penguasa sehingga akan memudahkan peneliti menjalani atau situasi sosial yang diteliti. Dalam penelitian ini yang menjadi adalah Chief Officer dan Boatswain. Sampel ini digunakan untuk mendapatkan data dengan wawancara, dengan pertimbangan bahwa Chief Officer dan Boatswain merupakan personil yang lebih banyak mengetahui tentang bagaimana cara merawat alat bongkar muat yang baik.

\section{E. Jenis Dan Sumber Data}

Pada penelitian ini penulis akan memberikan berbagai macam data yang bersifat kualitatif yang bersumber dari responden, baik secara lisan maupun secara tulisan berkaitan dengan yang penulis pelajari. Berbagai macam sumber data yang penulis pergunakan pada saat penyusunan penelitian adalah sebagai berikut:

\section{Sumber Data Primer}

Data primer dalam penyusunan penelitian ini adalah data yang didapat secara langsung dari sumbernya. Dalam hal ini data yang diambil dengan cara pengamatan dan wawancara dengan orang-orang yang terlibat secara langsung pada materi atau hal-hal yang berhubungan dengan materi yang penulis perlukan.

\section{Data Sekunder}

Data sekunder merupakan data yang diperoleh penulis sebagai data yang digunakan untuk mendukung atau melengkapi data yang sudah penulis dapatkan secara langsung. Data tersebut penulis dapatkan dari buku-buku, literatur, dan hasil penelitian lain yang mempunyai hubungan dengan apa yang penulis pelajari.

F. Metode Pengumpulan Data

Menurut Jonatan Sarwono dalam bukunya Metode Penelitian Kuantitatif dan Kualitatif (2006:222), menyatakan bahwa metode penggumpulan data adalah metode yang dilakukan melalui keterlibatan langsung dengan objek yang diteliti. Untuk mendapatkan data yang diperlukan dalam penelitian ini, maka metode pengumpulan data dilakukan dengan cara penelitian lapangan (Field Research). Penelitian lapangan ini dimaksudkan untuk memperoleh data primer, pengumpulan data primer diperoleh melalui wawancara atau interview dengan beberapa subjek yang paling banyak mengandung ciri-ciri, sifat-sifat dan karakteristik yang menjadi ciri-ciri yang sngat utama dari subjek subjek tersebut. Penulis menggunakan metode di bawah ini untuk memperoleh informasi yang diperlukan.

1. Studi Kepustakaan

Menurut Sukardi dalam bukunya Metodologi Penelitian Pendidikan (2008:33), studi kepustakaan adalah menelusuri dan mencari dasar-dasar acuan yang erat kaitannya dengan masalah penelitian yang hendak dilakukan, dasar-dasar tersebut tidak terbatas dari satu sumber saja tetapi dapat dicari dari berbagai sumber yang kemudian disusun dalam bab tersendiri. Sumber data dapat dilakukan dengan cara mengumpulkan data-data dari pembaca, meneliti dan mencatat serta mempelajari buku-buku maupun dokumen-dokumen yang ada diatas kapal maupun studi pustaka yang berhubungan dengan perawatan alat bongkar muat yang memiliki kaitan yang sangat erat dengan tujuan penulisan penelitian yang ditulis yaitu tentang rutinitas perawatan alat bongkar muat akan memperlancar kegiatan bongkar muat di atas kapal MV. Madison

\section{DISKUSI}

\section{A. Gambaran Umum Objek yang Diteliti}

Sesuai dengan judul yang diangkat penulis, yaitu "Optimalisasi penggunaan ships crane guna memperlancar proses 
bongkar muat MV. Madison di pelabuhan Nebire" maka sebagai depenelitian data, akan dijelaskan tentang keadaan sebenarnya yang terjadi di kapal, sehingga dengan depenelitian ini penulis mengharapkan agar pembaca mampu dan bisa merasakan tentang semua hal yang terjadi selama penulis melaksanakan penelitian. Kapal MV. Madison merupakan salah satu armada milik dari PT. Salam Pacific Indonesia dengan crewing company PT. Salam Pacific Indonesia Line Ship Management dengan alamat Jl. Karet No.104 Surabaya.

Kapal ini merupakan kapal yang besar yang dimiliki oleh PT.SPIL. Dengan jumlah armada yang banyak dan tersebar ke seluruh pelosok negeri. Kapal ini berjenis container ship's. Beroperasi dari ujung barat sampai ujung timur Indonesia yang berguna untuk membawa kebutuhan yang ada. Pengalaman penulis di Papua sangat berkesan. Bahwasanya perusahaan pelayaran sangatlah berpengaruh besar terhadap kemajuan di daerah yang sulit untuk akses pengirimannya. Bagaimana jadinya jika kapal yang membawa kebutuhan pokok tersebut mengalami kendala dan memiliki masalah dalam proses bongkar muatnya, penulis pun memiliki masalah yang akan dibahas dalam penelitian ini.

\section{B. Analisa Masalah}

Berdasarkan judul penelitian di atas, penulis menemukan 2 (dua) rumusan masalah, yaitu :

1. Apakah faktor yang menyebabkan rendahnya fungsi ship crane dalam proses bongkar muat?

Pada waktu penulis melaksanakan praktek MV. Madison pernah mengalami masalah pada saat bongkar muat di pelabuhan Nabire, yaitu terdapat pada peralatan bongkar muat yang membuat proses bongkar muat menjadi terganggu. Fokus permasalahan peralatan bongkar muat terdapat pada crane kapal. Dimulai dari permasalahan kurangnya perawatan terhadap wirecrane yang bisa menyebabkan wire putus, terbelit dan juga dapat memperlama proses bongkar muat. Kurangnya perawatan terhadap cargo block (kerek muat) yang menyebabkan menjadi aus karena gesekan antara wire crane dan cargo block, dan karat yang terdapat pada crane (batang pemuat derek) yang bisa menyebabkan crane terlepas dari lapisan pelindungnya. Sehingga perlu adanya pengoptimalan perawatan terhadap alat bongkar muat agar proses bongkar muat tidak terhambat. Kurangnya perawatan eletrik pada tuas kontrol yang terkadang merespon sangat lambat bahkan tidak sama sekali.

2. Bagaimana meningkatkan fungsi pengguaan ship crane pada proses bongkar muat di MV. MADISON ? Masalah-masalah yang muncul karena perawatan yang kurang baik terhadap alat bongkar muat, maka ada beberapa hal yang dapat dilakukan untuk mengoptimalkan proses bongkar muat yaitu dengan perawatan alat bongkar muat yang terjadwal sesuai dengan Planed Maintenance System (sistem perawatan yang terencana), yaitu pelaksanaan perawatan yang terdiri dari perawatan tahunan, perawatan bulanan dan perawatan mingguan. Perawatan yang dilakukan adalah dengan mengganti wirecrane, pengecekan spare partcrane (wire, cargo block) buatlah daftar permintaan kebutuhan kapal ke perusahaan jika sudah tidak ada suku cadang lagi yang tersedia di kapal, dan perawatan pembersihan karat pada batang pemuat crane. Pengaruh karat pada perawatan disebabkan oleh faktor dalam dan faktor luar. Faktor dalam karena kurangnya kesadaran crew terhadap kerugian yang disebabkan oleh karat, faktor luar karena alam (laut, angin, dll) yang terjadi yang menyebabkan proses karat pada alat bongkar muat menjadi lebih cepat. 
Dalam mengidentifikasi masalah di atas, ada beberapa hal yang perlu diperhatikan seperti kemampuan sumber daya manusia, tenaga, teknologi dan lain-lain. Untuk itu dilakukan penilaian prioritas masalah dari yang paling mendesak hingga tidak terlalu mendesak. Dalam menentukan prioritas masalah ini, penulis melakukan dengan menggunakan metode USG. Untuk dapat menentukan suatu masalah prioritas, terdapat 3 (tiga) faktor yang perlu dipertimbangkan sehingga dengan menentukan prioritas masalah penulis bisa mendapatkan judul yang nantinya akan dituangkan di dalam judul penelitian ini. Ketiga faktor tersebut adalah urgency, seriousness, dan growth (USG).

Dalam pencarian rumusan masalah yang digunakan dalam rumusan USG, penelitian yang dibuat dengan metode ini diharapkan lebih memliki pemaparan yang ringkas dan lengkap. Agar tidak memiliki dan timbul pertanyaan berikutnya.

Tabel Prioritas masalah melalui USG

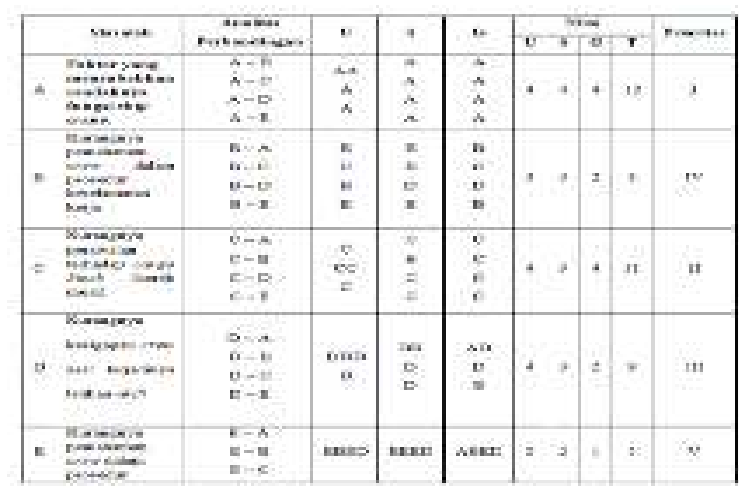

Berdasarkan metode prioritas masalah di atas maka masalah utama yang harus segera diselesaikan adalah masalah perawatan terhadap alat bongkar muat (deck crane), agar proses bongkar muat di kapal dapat berjalan dengan efektif dan efisien. Dari permasalahan yang disebutkan akan dijabarkan oleh penulis.
1. Faktor yang menyebabkan rendahnya fungsi ship crane.

Berdasarkan dengan apa yang telah penulis amati di atas kapal, penulis menemukan beberapa hal yang menyebabkan perawatan peralatan bongkar muat menjadi tidak baik, diantaranya disebabkan oleh sebagai berikut:

a. Kurangnya perawatan terhadap wire (kawat) yang menyebabkan wire putus, antara lain :

1) Keterlambatan mengganti wire (kawat)

Keterlambatan penggantian wire crane (kawat batang pemuat derek), meskipun sudah melewati batas yang diizinkan yaitu 1 tahun, tetap saja digunakan sampai wire benar-benar terlihat tidak aman lagi bagi proses bongkar muat baru wire diganti.

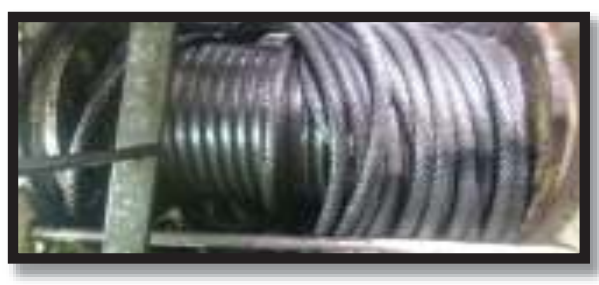

Gambar Putusnya wire akibat jarang dirawat

2) Keterlambatan pengecekan spare part wire crane (suku cadang kawat batang pemuat derek) dan kualitas spare part yang tidak baik.

Keterlambatan pengecekan spare part crane (suku cadang batang pemuat derek) sering terjadi sehingga bila wire mengalami kerusakan maka tidak bisa langsung diganti pada saat itu juga dan harus menunggu dari perusahaan untuk mengirimkan spare part wire yang dibutuhkan sehingga terjadi pemborosan waktu. Spare part wire merupakan salah satu unsur dalam perawatan crane karena tanpa pengadaan spare part wire maka crane tidak akan berfungsi dan 
tidak dapat beroperasi dengan maksimal, untuk itu dalam pemilihan spare part wire juga tidak bisa sembarangan dan harus yang sesuai dengan jenis dan nomer serinya. Tetapi pada kenyataannya yang diteliti oleh penulis pada kapal, spare part wire dari crane yang dikirim oleh perusahaan ke kapal tidak sesuai dengan requestion (permintaan) yang dibuat oleh chief officer sebelum meminta spare part wire, kadang perusahaan juga memberikan kualitas spare part wire yang jelek atau pilihan kedua selain yang diminta oleh pihak kapal.

3) Keterlambatan pelumasan terhadap wire

Keterlambatan pelumasan terhadap wire menyebabkan wire mengeras dan menjadi kaku sehingga mempercepat kerusakan pada wire. Selama penulis melaksanakan penelitian saat praktek laut, pelumasan terhadap wire hampir tidak pernah dilaksanakan oleh.

Crew kapal, biasanya apabila dilaksanakan pelumasan wire tidak dibersihkan terlebih dahulu, namun langsung diberi grease (gemuk). Itu menyebabkan kotoran-kotoran yang menempel pada wire masih ada saat sudah diberi grease, maka wire lamakelamaan akan kaku dan rusak.

2. Kurangnya pemahaman crew dalam prosedur keselamatan kerja

Berdasarkan apa yang ditulis dan diamati di atas kapal bahwasanya yang terjadi di lapangan kurangnya kepedulian crew dalam keselamatan dirinya masing-masing. Sehingga menyebabkan beberapa masalah yang disebabkan beberapa hal sebagai berikut: a. Kurangnya peralatan perorangan di kapal

Hal ini sangat berpengaruh terhadap kinerja dan profesional setiap crew kapal. Peralatan yang penting dan jarang diperhatikan adalah masalah helmet yang digunakan oleh para crew. Perlatan lain seperti baju kerja, safety shoes, sarung tangan, kacamata dan pelindung telinga. Ini sangat jarang diperhatikan dalam pekerjaan seharihari.

Seringnya terjadinya kecelakaaan di laut akibat kelalaian ini terkadang juga masih tidak membuat sadar crew di atas kapal. Beberapa hal yang kurang diperhatikan adalah:

1) Kurangnya supply alat keselamatan oleh perusahaan

Pelayaran yang memiliki permasalahan ini sangatlah penting karena bagaimana crew menggunakan alat keselamatan jika kurangnya alat keselamatan yang ada di atas kapal. Pergantian alat keselamatan yang telah rusak terkadang terlambat sehingga para crew kapal bertahan dangan alat keselamatan yang sudah rusak dan tidak maksimal.

2) Kurangnya audit untuk para crew.

Permasalahan ini terjadi akibatnya kurang ketatnya peraturan perusahaan terhadap crew yang melanggar. Jadi ada efek jera untuk para crew yang melanggar peraturan perusahaan. Mengubah paradigma lama crew kapal yang biasanya tidak ada apa-apa sewaktu-waktu dapat berubah dan mengakibatkan masalah.

3. Kurangnya perawatan terhadap cargo block (kerek muat).

Dalam hal ini komponen yang penting yaitu cargo block yang merupakan jalannya wire yang 
dapat mempermudah proses perputaran wire. Beberapa hal yang dapat mengurangi kinerja cargo block antara lain:

a. Keterlambatan mengganti cargo block

Keterlambatan mengganti cargo block dikarenakan harganya yang mahal sehingga meskipun sudah melewati batas waktu layak pakai yang sudah diizinkan, tetap saja digunakan sampai cargo block benar-benar aus dan terlihat tidak aman lagi bagi proses bongkar muat.

b. Keterlambatan pengecekan spare part cargo block

Keterlambatan pengecekan spare part cargo block sangat sering terjadi sehingga apabila cargo block mengalami kerusakan maka tidak bisa langsung diganti pada saat itu juga dan harus menunggu dari perusahaan untuk mengirim spare part cargo block tersebut sehingga terjadi pemborosan waktu. Spare part cargo block adalah salah satu unsur dalam perawatan crane karena tanpa pengadaan spare part cargo block maka crane tidak akan berfungsi dan tidak dapat beroperasi dengan maksimal, untuk itu dalam pemilihan spare part juga tidak bisa sembarangan dan harus yang sesuai dengan jenis dan nomor serinya.

Tetapi pada kenyataannya yang penulis teliti pada kapal, spare part cargo block dari crane yang dikirim oleh perusahaan ke kapal tidak sesuai dengan requitition (permintaan) yang dibuat oleh chief officer sebelum meminta spare part cargo block, terkadang perusahaan juga memberikan kualitas spare part cargo block yang jelek atau pilihan kedua selain yang diminta oleh pihak kapal.
4. Kurangnya kesigapan crew saat terjadinya latihan drill

Rendahnya kedisiplinan crew dalam mentaati peraturan dalam prosedur penanganan terjadinya tubrukan di atas kapal. Tidak pernah mengecek alat-alat elektronik sebagai media bantu untuk pelaksanaan suatu kegiatan. Seperti, ullage monitoring tidak pernah dikoreksi sehingga terjadi salah penunjukkan yang mengakibatkan permasalahan baru pada aktifitas bongkar muat. Adapun penyebab apabila crew kurang melakukan latihan drill.

a. Perusahaan sengaja atau tidak sengaja terlambat mengirim peralatan-peralatan keselamatan atau peralatan lain yang sangat penting dalam pengoperasian kapal dan biasanya pihak perusahaan akan mengirimnya apabila kapal akan diaudit. Pemahaman crew yang kurang dalam melaksanakan kerja. Ini diakibatkan karena kurangnya pengetahuan dan pengalaman bekerja di kapal atau rendahnya sumber daya yang dimiliki oleh crew tersebut.

b. Peralatan yang sudah tidak layak pakai memungkinkan besarnya terjadi resiko kecelakaan pada waktu bekerja di lapangan. Disini Nakhoda mengatakan bahwa dengan ketidaklayakan peralatan tersebut maka pekerja enggan menggunakannya, ini juga merupakan salah satu pemicu terjadinya kecelakaan.

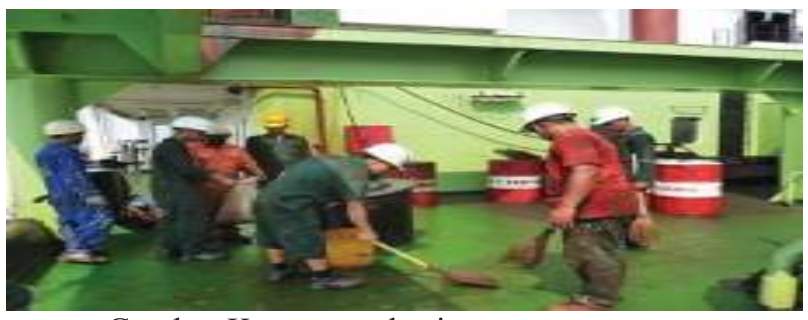

Gambar Kurangnya kesigapan crew saat melakukan drill 
5. Kurangnya pemahaman crew dalam prosedur keselamatan kerja.

Dibutuhkan peran serta perwira di atas kapal dalam suatu organisasi kerja dan pengetahuan personil terhadap penanganan kompartemen tertutup serta penggunaan peralatan dalam menunjang kelancaran seluruh rangkaian kegiatan kerja. Penerapan manajemen dalam menangani pekerjaan-pekerjaan di dalam kompartemen tertutup di MV. Madison dapat berjalan dengan baik, disebabkan adanya usaha-usaha meningkatkan pengetahuan dan kemampuan anak buah kapal sebagai tindakan antisipasi terhadap terjadinya kecelakaan kerja di dalam kompartemen-kompartemen tertutup. Berdasarkan yang ditemukan di atas kapal dapat diajukan. Dalam menangani pekerjaan-pekerjaan di dalam kompartemen tertutup di atas kapal container, tindakan antisipasi kecelakaan kerja terhadap awak kapal yang bekerja di dalamnya harus menjadi prioritas utama.

Perencanaan yang matang, pembentukan organisasi yang tepat, pelatihan-pelatihan keselamatan kerja, pengarahan-pengarahan, dan tindakan pengendalian serta pengawasan diharapkan dapat menekan terjadinya kecelakaan kerja dalam menangani pekerjaanpekerjaan di dalam kompartemenkompartemen tertutup seperti yang dilakukan di MV. Madison dan sesuai dengan pedoman yang dibuat oleh Mualim I dengan mengacu konvensi SOLAS.

\section{Pembahasan Masalah}

Berdasarkan judul penelitian di atas, penulis menemukan 2 (dua) rumusan masalah, yaitu :

1. Apakah faktor yang menyebabkan rendahnya fungsi ship crane dalam proses bongkar muat? a) Faktor luar

Faktor luar ini sendiri banyak menyebabkan kurangnya fungsi batang pemuat itu sendiri yang di mana batang pemuat sangat berpengaruh dalam pengangkutan muatan. Apabila batang pemuat terjadi kerusakan maka akan terjadi kecemasan mampukah batang pemuat ini mengangkut beban yang tertera di SWL. Bukan hanya batang pemuat di badan crane sendiri bnyak sekali kerusakan yaitu :

1) Kurangnya perawatan crane

Kurangnya perawatan crane sangat mempengaruhi kinerja crane tersebut sehingga menurunkan kinerja dari crane. Berikut perawatan crane yang seharusnya dilakukan di atas kapal:

a. Penundaan pengecekan karat pada crane.

Penundaan pengecekan karat pada batang pemuat crane dapat menyebabkan kekuatan daya muat pada crane berkurang. Biasanya karat kurang mendapat perhatian dari pihak kapal yang sebenarnya bila diamati kerugian yang ditimbulkan oleh karat sangatlah besar.

b. Permukaan logam

Permukaan logam yang tidak rata memudahkan terjadinya kutub-kutub muatan, yang akhirnya akan berperan sebagai anode dan katode.

2) Keterlambatan pengecatan pada crane (batang pemuat derek)

Keterlambatan pengecatan pada batang pemuat crane yang menyebabkan proses karat semakin cepat terjadi kembali sehingga kekuatan crane menjadi berkurang. Selama penulis melaksanakan praktek laut di 
kapal, crew kapal kurang peduli terhadap perawatan crane terutama pengecatan crane.

3) Banyaknya alat yang tidak layak

Penggunaan crane secara terus-menerus tanpa ada peraatan dan pergantian komponen yang rusak atau yang sudah waktunya diganti dapat menyebabkan kurangnya fungsi crane tersebut. Hal ini banyak disepelekan karena harga spare part yang harus diganti mahal ataupun barang yang sudah tidak ada sehingga tambal sulam atau menggunakan spare part yang masih layak.

4) Keterlambatan pelumasan (pemberian grease) terhadap wire

Keterlambatan pelumasan terhadap wire menyebabkan wire mengeras dan menjadi kaku sehingga mempercepat kerusakan pada wire. Selama penulis melaksanakan penelitian pada waktu praktek laut, crew kapal melakukan pelumasan terhadap wire biasanya dilaksanakan dengan wire tidak dibersihkan terlebih dahulu tetapi langsung diberi grease (gemuk), sehingga kotoran-kotoran yang menempel pada wire masih ada walaupun sudah terlanjur diberi grease yang baru maka wire lama-kelamaan akan kaku dan rusak.

b) Faktor dalam

Faktor ini merupakan permasalahan yang timbul dari lingkup kapal sendiri dalam perawatan kapal terhadap karat. Faktor dalam yang terjadi di kapal penulis meliputi:

1) Kurangnya kesadaran crew kapal terhadap kerugian yang disebabkan karat.
2) Pengadaan spare part yang kurang ditanggapi perusahaan. Dalam hal ini spare part sangat di butuhkan dalam menunjang optimalnya fungsi crane itu sendiri. Perusahaan kadang mengetahui bahwa spare part itu dibutuhkan seperti wire, cargo block, cat, grease, dan lain-lain.

2. Bagaimana meningkatkan fungsi penggunaan crane pada proses bongkar muat MV. Madison?

Pada saat melakukan pemberian pemahaman kepada crew kapal menurut PMS atau Planed Maintenance System (sistem perawatan yang terencana) untuk merawat peralatan bongkar muat dalam hal ini batang pemuat crane, crew kurang dapat menangkap yang dimaksud perawatan yang terencana.

a. Meningkatkan perawatan dan fungsi crane kapal

Untuk meningkatkan fungsi crane kapal dibutuhkan perawatan yang dapat membuat kondisi crane agar tetap optimal dan dapat digunakan setiap saat. Perawatannya pun berbagai macam dan berkala. Adapun perawatan yang dilakukan adalah:

1) Pelaksanakan perawatan pada waktu-waktu yang dijadwalkan:

a) Perawatan tahunan

Pada perawatan tahunan hal-hal yang perlu dilaksanakan dalam proses mewujudkan kelancaran bongkar muat yang ditunjang oleh peralatan bongkar muat khususnya dalam penggunaan crane kapal.

1. Mengganti wire (tali kawat)

2. Pengecekan spare part (suku cadang) crane dan membuat requisition 
(permintaan) ke perusahaan.

3. Pembersihan karat dan pengecatan pada batang pemuat crane secara keseluruhan.

\section{b) Perawatan bulanan}

Berdasarkan pengalaman yang dialami penulis selama menjalankan praktek laut, pengecekan wire dilakukan oleh anak buah kapal saat melakukan greasing (pelumasan) harus pelan-pelan yang bertujuan mengecek secara detail kondisi wire tersebut.

c) Perawatan mingguan

Berdasarkan yang terjadi di lapangan mingguan tidak efektif karena pelayaran yang pendek tidak sangat memungkinkan untuk melakukan perawatan karena trip yang pendek.

b. Beberapa tes untuk mengetahui kelaikan crane

- Pengujian Beban

Pengujian beban dilaksanakan meliputi pengujian dinamis dan statis

mana pengujian dinamis adalah

pada beban s/d beban maksimu m SWL.

Pengujian statis dilaksanakan pa da beban $100 \% \quad-125$ $\%$ X SWL maksimum dengan posisi beban uji kurang lebih 3 $0 \quad \mathrm{Cm}$ di atas lantai dan ditahan selama 10 menit.

\section{KESIMPULAN}

Dari hasil yang diperoleh dalam penelitian oleh penulis, dapat disimpulkan bawa:

1. Peralatan bongkar muat yang di gunakan di atas kapal sangat penting kegunaaanya, khususnya crane. Oleh sebab itu perawatan dan penggunaannya perlu diperhatikan.

2. Kesadaran crew yang kurang dan pemahaman yang sangat minim dalam melakukan perawatan crane kapal, serta perusahaan yang tidak melihat kesiapan armadanya yang akan digunakan. Sehingga bila terjadi sesuatu dapat menghambat bongkar muat dan perusahaan sendiri akan mengalami kerugian karena keuntungan yang kecil.

3. Kerusakan yang terjadi pada crane kebanyakan terjadi akibat kelalaian para crew kapal yang terlalu mengabaikan. Serta kepedulian perusahaan yang kurang terhadap optimalisasi crane di atas kapal.

4. Kendala yang dialami ketika berada di Nabire yang diakibatkan fungsi crane yang kurang optimal, yang mengakibatkan keterlambatan proses bongkar muat.

5. Kurangnya kepedulian perusahaan akan pengadaan spare part untuk crane yang akan digunakan untuk bongkar muat. Dari kekurangan inilah crane akan menjadi tidak terawat.

Dalam hal ini penulis akan memberikan beberapa saran yang dapat bermanfaat bagi crew kapal dan perusahaan dengan dilengkapi beberapa keteranganketerangan yang akan membuat semakin majunya perusahaan dan meningkatnya kesadaran crew tentang peralatan bongkar muat. Adapun beberapa saran yang akan disebutkan :

1. Hendaknya perawatan terhadap peralatan bongkar muat khususnya crane dilakukan secara rutin, tidak menunggu sampai peralatan bongkar muat rusak terlebih dahulu mengakibatkan keterlambatan dan kerugian terhadap perusahaan pelayaran 
tersebut. Sehngga mengakibatkan terlambatnya bongkar muat. Sebaiknya meningkatkan kesadaran dan pemahaman crew kapal untuk melakukan perawatan peralatan bongkar muat sesuai dengan PMS (Planned Maintenance System). Dengan memiliki crew yang memiliki kinerja yang baik maka akan meningkatkan kinerja alat bongkar itu sendiri.

2. Menyediakan waktu untuk merawat peralatan bongkar muat di mana waktu tersebut tidak terbentur oleh kegiatan operasi kapal. Menyediakan peralatan dan spare part yang berkualitas sehingga dapat menunjang dalam pelaksanaan perawatan peralatan bongkar muat. Menyediakan perlengkapan keselamatan bagi crew kapal agar meningkatkan kesadaran crew akan pentingnya keselamatan saat bekerja dan juga keselamatan crew yang dilatih untuk menghadapi permasalahan-permasalahan yang ada di kapal. Pembenaran jadwal yang harus dikoordinasikan untuk perawatan crane, dan konsistensi dalam pengerjaannya.

\section{DAFTAR PUSTAKA}

Wahyuningsih. 2010. Kamus Bahasa Indonesia, Edisi Baru, Edisi ketiga. Jakarta: Balai Pustaka

Abdillah, Pius dan Danu Prasetya. 2009. Kamus Lengkap Bahasa Indonesia. Surabaya: Arkola

Martopo, Arso dan Soegiyanto. 2004. Penanganan dan Pengaturan Muatan. Semarang: Politeknik Ilmu Pelayaran Semarang

Sukardi. 2008. Metodologi Penelitian Pendidikan. Jakarta: PT. Bumi Aksara
Moleong, Lexy J. 2006. Metodologi Penelitian Kualitatif. Bandung: PT. Remaja Rosdakarya

Kepner, C. H. dan Benjamin B. Tregoe. 1981. Manajer Yang Rasional. Edisi Terjemahan. Jakarta: Penerbit Erlangga

Nawawi, Handari. 1998. Metodologi Penelitian Pendidikan. Yogyakarta: Gadjah Mada Universitas Press

Nasution, S. 2006. Metode Research. Surabaya: Penerbit Bumi Aksara

Sarwono, Jonathan. 2006. Metode Penelitian Kuantitatif dan Kualitatif. Yogyakarta: Graha Ilmu

Tim Penyusun Departemen Pendidikan Nasional. 2008. Kamus Besar Bahasa Indonesia. Jakarta: Balai Pustaka

NSOS. 1990. Manajemen Perawatan dan Perbaikan.

Istopo. 1999. Kapal dan Muatannya. Jakarta: Koperasi Karyawan BP3IP 